\title{
The Hedonic Pricing Model Applied to the Housing Market
}

\author{
Submitted 11/04/20, $1^{\text {st }}$ revision 19/05/20, $2^{\text {nd }}$ revision 25/06/20, accepted 30/07/20
}

\section{Abstract:}

$$
\text { My-Linh Thi Nguyen }{ }^{1}
$$

Purpose: The article applies the hedonic pricing model to estimate house price in the housing market of Vietnam, which is a country with a fledgeling housing market, so the study is expected to bring interesting findings.

Design/Methodology/Approach: By applying the hedonic pricing model, most of the previous studies have reported that house price is significantly influenced by the characteristics of the house itself, its location and surrounding facilities. Based on this, the article adopts the Ordinary Least Squares (OLS) regression in combination with robustness statistics in the model estimation, so the estimated results on house price are reliable and able to be widely applied. Data are collected through the survey into housing projects in Ho Chi Minh and Ha Noi city, which are the two largest cities in Vietnam.

Findings: The findings reveal that the hedonic pricing model can be applied to estimate house price in Vietnam's housing market. This can be said to be a big success in giving first empirical evidence in Vietnam on this matter. Specifically, house price is negatively affected by its proximity to the city center. Also, factors including house size, house type, house structure, number of bedrooms, amenities around the house exert a positive influence on the price.

Practical Implications: The estimated results are typical and reliable, which can be applied universally.

Originality/Value: The study confirms the hedonic pricing model can be well-applied to accurately estimate the price of houses in Vietnam. More than that, the findings are also essential for other countries, especially those with a nascent housing market like Vietnam.

Keywords: Hedonic pricing model, house price, housing market, real estate, Vietnam.

JEL: C53, E37, R32.

Paper Type: Research article.

\footnotetext{
${ }^{1}$ Assoc. Prof. Faculty of Finance and Banking, University of Finance-Marketing (UFM), Ho Chi Minh city, Vietnam. E-mail: ntmylinh@ufm.edu.vn.

ORCID ID: 0000-0001-7475-2502
} 


\section{Introduction}

To make an accurate prediction on house price is really important to prospective homeowners, investors, appraisers, tax assessors and other housing market participants (Frew and Jud, 2003). Traditional house price prediction is based on cost and the relationship between demand and supply. This usually leads to the house price is much higher than its real value, even the appearance of bubbles in the housing market (Bui, 2019). Therefore, it is essential to identify determinants of house price, thereby making a precise prediction and improving the efficiency of the market. Further, operations in the housing market are performing fast, efficiently, which are beneficial for the participants.

In Vietnam, housing demand is highly increasing, especially in metropolitan areas (Nguyen et al., 2019; Bui, 2020a; Nguyen and Do, 2020). This is because a great number of inter-provincial migrants tend to move to big cities (Bui, 2020b) while the availability of land is limited. On the other hand, most Vietnamese wish to possess their own house, instead of renting one. More than that, handful of investors have participated in the housing market with the expectation of a high profit from this market. This gives a considerable increase in house price, possibly occurring real estate bubbles (Bui, 2019). In fact, changes in house price in Vietnam's housing market are unpredictable. This can be clearly described through house price index in Ho Chi Minh and Ha Noi city, the two biggest metropolises of Vietnam, which is quarterly published by Savills Vietnam (Figure 1).

Indeed, after the global financial crisis, Vietnam's housing market gained significant growth in the 2009-2011 period, proving that the post-crisis policies aimed to recover the economy have achieved positive benefits in the housing market. However, right after that, in order to recover the economy as well as minimize the risks of crisis reoccurrence in the real estate market, Vietnam started to perform tight monetary policies toward real estate industry, making the housing market face lots of difficulties and considerably fell in 2013. Recently, the housing market has recovered and gradually increased. Also, transactions in the housing market have been proceeded more smoothly.

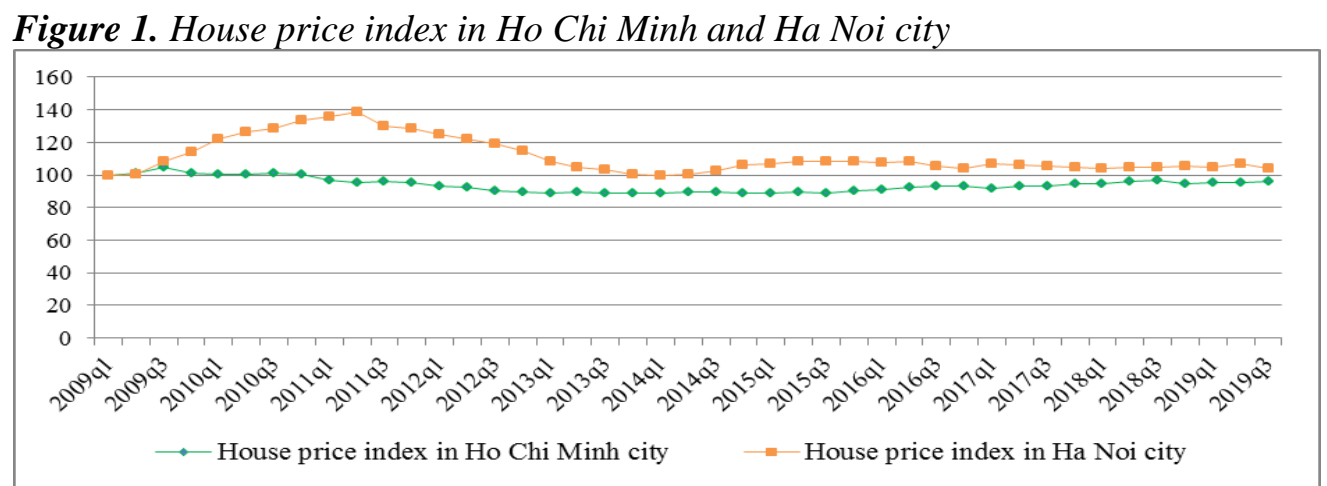


Constant fluctuations in the housing market confuse and worry its participants (Schulz and Werwatz, 2004; Jeon, 2018; Nguyen and Bui, 2019). They also make the managers hesitate in giving suitable management policies (Nguyen et al., 2020). Therefore, to determine influential factors of house price is necessary. It provides the participants a reliable base for an accurate prediction on house price. This research problem has been examined in some empirical studies, wherein the hedonic pricing model has been frequently applied in predicting the house price.

Nevertheless, these studies have their drawbacks of being unable to reach an agreement on the determinants of house price. Also, there exist lots of difficulties in collecting data on traded houses. Therefore, most of them can only obtain smallscale data which cannot fully represent for the entire market, leading to unreliable results which are unable to be used widely. This is a big gap in the current literature.

Moreover, most of them have been conducted in developed countries with a lack of empirical studies in countries with nascent housing market. By this study, the article expects to contribute to the current literature with an accurate estimation on the house price in Vietnam through applying the hedonic pricing model. The data are obtained from the survey of housing projects which were successfully traded in Ho Chi Minh and Ha Noi city, the two biggest cities of Vietnam. In Vietnam, a majority of trading in the housing market has mainly been conducted in metropolises, so the dataset utilized is expected to be highly representative. Particularly, by collecting the data in the recent period, the study is expected to accurately reflect the actual developments in the housing market as well as reveal unprecedented findings.

\section{Literature Review and Research Hypothesis}

Housing market is defined as the market for properties being sold, purchased, rented or differently traded, thereby forming prices (Bui, 2020b). Thus, it is traditionally measured by house price. In fact, this problem has been empirically investigated in developed countries while few empirical studies have been conducted in places with nascent housing market. The application of the hedonic pricing model has been widely done in a big number of previous studies. Specifically, house price is usually determined by internal characteristics, its location and surrounding facilities. In order to estimate the price of home by applying the hedonic pricing model, obtaining data on traded houses is a prerequisite.

One of the advantages is that hedonic pricing uses regression to estimate house price, which can overcome drawbacks of traditional valuation methods. For example, it can minimize the big subjective influence of appraisers on house value like other methods. Furthermore, the hedonic pricing model can help reduce estimation cost if being widely applied (Peterson and Flanagan, 2009; McCluskey et $a l ., 2013)$. As a result, this application is frequently a good choice in house price valuation (Peterson and Flanagan, 2009; Lin and Mohan, 2011; Zurada et al., 2011; Antipov and Pokryshevskaya, 2012; McCluskey et al., 2012; Renigier-Biłozor et al., 
2019). This model is even used to test the estimation results of other traditional models (Nghiep and Al, 2001; Friesen et al., 2011; Kilpatrick, 2011; Kontrimas and Verikas, 2011). With lots of outstanding advantages, the hedonic pricing model has been applied in the U.S since 1920 (Abidoye and Chan, 2017). Nowadays, it has been utilized in many developed countries.

However, most empirical studies using this model have their drawbacks when unable to collect adequate dataset which can represent the entire market. It is because there still exist many difficulties in data collection of traded housing projects, particularly in a country with a young housing market. This leads to a big number of errors in the application of estimated results suggested in the previous studies. Consequently, if this matter can be well-controlled, the results of the model application are more reliable, which can be practically applied widely. Based on the current literature, it can be recognized that the price of a house is frequently affected by house size, house type, house structure, number of bedrooms, number of bathrooms, the proximity to the city center, included amenities (such as hot-tub, swimming pool) and local amenities (such as parks, squares, schools, shopping malls), which are comprised in this study.

\subsection{The Impact of House Size on House Price}

A house in big size is frequently more preferred, particularly by crowded families. It is because big houses are able to provide larger and more comfortable space. Some families can even utilize their house for business or offices. Hence, houses in big size are more valuable (Kain and Quigley, 1970; Selim, 2009; Amenyah and Fletcher, 2013; Shimizu, 2014; Yayar and Demir, 2014; Ndegwa, 2018). Based on this, the article suggests the research hypothesis as follows:

$\boldsymbol{H}_{1}$ : House size (SIZE) has a positive impact on house price (PRICE).

\subsection{The Impact of the Number of Bedrooms on House Price}

Houses with more bedrooms are likely more expensive because they meet the demand of big families. These houses can provide enough private space for each family member. Further, they are more convenient for their friends or relatives to stay over. Therefore, the number of bedrooms positively affects the house's value. This result is also in line with what have been found by Kain and Quigley (1970), Cebula (2009), Selim (2009), Baek et al. (2019). Hence, the research hypothesis is suggested as follows:

$\mathrm{H}_{2}$ : The number of bedrooms (BEDROOMS) has a positive impact on house price (PRICE).

\subsection{The Impact of the Number of Bathrooms on House Price}


Kain and Quigley (1970), Cebula (2009) reported that the number of bathrooms are positively correlated to house price. Indeed, the number of bathrooms meets basic needs of households. Although bathrooms are considered as a must to be present in a house, this factor has received much attention in many empirical research. Therefore, the research hypothesis is proposed as follows:

$H_{3}$ : The number of bathrooms (BATHROOMS) has a positive impact on house price (PRICE).

\subsection{The Impact of House Location on House Price}

A house which is close to the center area of a city or a town tends to be a preferential choice to buyers. This facilitates the commute to the downtown area or work. This also allows families enjoy more facilities and services nearby. In addition, houses close to the center are easily sold or rented at a steep price. These houses may thus sell for a premium. Alternatively, houses with a further distance from the center may sell for less. This influence corroborates with the findings of Selim (2009), Aluko (2011), Amenyah and Fletcher (2013), Yayar and Demir (2014), Ndegwa (2018). Based on this, the article proposes the research hypothesis as follows:

$\boldsymbol{H}_{4}$ : The proximity to the center (CENTER) has a negative impact on house price (PRICE).

\subsection{The Impact of House Type on House Price}

Type of a house is a big consideration of house buyers. In fact, houses with a garden can help create green space and significantly improve the living standard. These houses, thus, are more preferred and priced (Limsombunchai et al., 2004). Therefore, the research hypothesis is suggested as follows:

H5: $_{5}$ Type of house (the house has a garden) (TYPE) has a positive impact on house price (PRICE).

\subsection{The Impact of House Amenities on House Price}

A house is more valued with lots of amenities including pools, hot-tubs (Laurice and Bhattacharya, 2005; Sirmans et al., 2005; Cebula, 2009; Yayar and Demir, 2014). The presence of swimming pools or hot-tubs obviously satisfies basic needs and improves a family's standard of living. Therefore, the research hypothesis is suggested as follows:

H6: House amenities (POOL) have a positive impact on house price (PRICE).

\subsection{The Impact of Local Amenities on House Price}


Local amenities significantly influence the price of a house. Houses close to parks, squares, schools or shopping malls facilitate households' entertainment, study or shopping. Housing projects, thus, tend to pay more attention on their public amenities. Those houses are more preferred and expensive (Cebula, 2009; Selim, 2009; Amenyah and Fletcher, 2013; Ndegwa, 2018). Therefore, the research hypothesis is proposed as follows:

H7: Local amenities (PARK) have a positive impact on house price (PRICE).

\subsection{The Impact of House Structure on House Price}

A house with a new and modern structure is easily sold at a higher value. Indeed, beside their living demands, buyers are looking forward to owning modern newbuild houses. Thus, these houses are highly priced (Cebula, 2009). Hence, the article suggests the following research hypothesis:

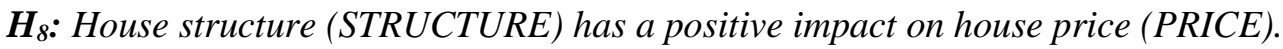

Table 1. Research Hypotheses

\begin{tabular}{|l|l|l|}
\hline No & Hypothesis & $(+)$ \\
\hline $\mathrm{H}_{1}$ & SIZE $\Rightarrow$ PRICE & $(+)$ \\
\hline $\mathrm{H}_{2}$ & BEDROOMS $\Rightarrow$ PRICE & $(+)$ \\
\hline $\mathrm{H}_{3}$ & BATHROOMS $\Rightarrow$ PRICE & $(-)$ \\
\hline $\mathrm{H}_{4}$ & CENTER $\Rightarrow$ PRICE & $(+)$ \\
\hline $\mathrm{H}_{5}$ & TYPE $\Longrightarrow$ PRICE & $(+)$ \\
\hline $\mathrm{H}_{6}$ & POOL $\Rightarrow$ PRICE & $(+)$ \\
\hline $\mathrm{H}_{7}$ & PARK $\Rightarrow$ PRICE & $(+)$ \\
\hline $\mathrm{H}_{8}$ & STRUCTURE $\Rightarrow$ PRICE & \\
\hline
\end{tabular}

Source: Own study.

\section{Methodology}

In this study, the article adopts the hedonic pricing model to estimate the house price in Vietnam. The article collects survey data of 205 houses which were successfully traded in Ho Chi Minh and Ha Noi city in the first six months of 2019. By the collection of data survey, the study is expected to accurately reflect the actual developments in housing market as well as reveal unprecedented findings.

Regarding the analysis, the Ordinary Least Squares (OLS) regression is employed to estimate the research model. If the hypotheses are violated, the article would adopt other suitable quantitative analyses to control, such as robustness statistics, following what was suggested by White (1980).

Based on the hedonic pricing model, the previous results and the above-developed hypotheses, the research model is estimated as follows: 
PRICE $=\beta_{0}+\beta_{1}$ SIZE $+\beta_{2}$ BEDROOMS $+\beta_{3}$ BATHROOMS $+\beta_{4}$ CENTER $+\beta_{5}$ TYPE $+\beta_{6}$ POOL $+\beta_{7}$ PARK $+\beta_{8}$ STRUCTURE $+\varepsilon$

Where: Dependent variable (PRICE): House price (price per square meter).

Independent variables: SIZE: House size (square meters); BEDROOMS: Number of bedrooms; BATHROOMS: Number of bathrooms; CENTER: Proximity to the city center (kilometers); TYPE: A binary variable indicating whether the house has a garden ( $=1$ if yes, $=0$ otherwise); POOL: A binary variable indicating whether the house has its amenities such as a hot-tub and/or a swimming pool (= 1 if yes, $=0$ otherwise); PARK: A binary variable indicating whether the house has local amenities such as parks, squares, schools or shopping malls $(=1$ if yes, $=0$ otherwise); STRUCTURE: A binary variable indicating whether the structure is new and modern ( $=1$ if yes, $=0$ otherwise); $\varepsilon$ : Error term; $\beta_{\mathrm{i}}$ : Coefficients; $\beta_{0}$ : Constant.

\section{Empirical Results}

First, the article analyses the correlation among the variables. The result is shown in Table 2 as follows:

Table 2. Variable correlations

\begin{tabular}{|c|c|c|c|c|c|c|c|c|c|}
\hline & त्र & $\stackrel{n}{\mathrm{~N}}$ & 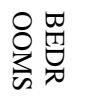 & 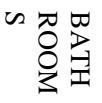 & 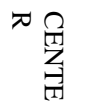 & 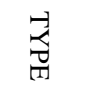 & $\underset{ٍ}{ٍ}$ & $\vec{D}_{\pi}^{D}$ & 氠 \\
\hline PRICE & 1.000 & & & & & & & & \\
\hline SIZE & 0.128 & 1.000 & & & & & & & \\
\hline BEDROOMS & 0.776 & 0.146 & 1.000 & & & & & & \\
\hline BATHROOMS & 0.546 & 0.167 & 0.656 & 1.000 & & & & & \\
\hline CENTER & -0.590 & 0.010 & -0.473 & -0.369 & 1.000 & & & & \\
\hline TYPE & 0.595 & -0.046 & 0.429 & 0.315 & -0.300 & 1.000 & & & \\
\hline POOL & 0.011 & 0.017 & 0.025 & 0.005 & -0.037 & -0.002 & 1.000 & & \\
\hline PARK & 0.776 & 0.082 & 0.471 & 0.334 & -0.413 & 0.615 & -0.044 & 1.000 & \\
\hline STRUCTURE & 0.712 & -0.092 & 0.536 & 0.370 & -0.422 & 0.435 & 0.017 & 0.661 & 1.000 \\
\hline
\end{tabular}

Source: Own study.

Table 2 reveals that the distance from the house to the center (CENTER) is negatively correlated to its price (PRICE) while the other independent variables are positively associated with the house price (PRICE). This is in line with what the article has been suggested previously.

Table 3. Results of tests on multicollinearity, heteroscedasticity

\begin{tabular}{|l|l|l|}
\hline \multicolumn{2}{|l|}{ Multicollinearity test } & \multirow{2}{*}{ Heteroscedasticity test } \\
\hline Variable & VIF & \\
PARK & 2.52 & Chi2 $(42)=89.01$ \\
\hline BEDROOMS & 2.36 & Prob $>$ chi2 $=0.000^{* * *}$ \\
\hline STRUCTURE & 2.18 & \\
\hline BATHROOMS & 1.79 & \\
\hline
\end{tabular}




\begin{tabular}{|l|l|l|}
\hline TYPE & 1.73 \\
\hline CENTER & 1.41 \\
\hline SIZE & 1.14 \\
\hline POOL & 1.01 \\
\cline { 1 - 1 } Mean VIF $=1.77$ & \\
\hline
\end{tabular}

Note: ${ }^{* * *}$ indicates significance at the $1 \%$ level.

Source: Own study.

The model is considered to experience no serious issues of multicollinearity (Mean VIF $=1.77)$. However, heteroscedasticity really exists at the $1 \%$ level of significance (Prob $>$ chi $2=0.000)$ (Table 3 ). This means that the estimation using the Ordinary Least Squares regression (OLS) does not provide a reliable result. Thus, robustness statistics is utilized for the estimation, following what have been suggested by White (1980) and recently performed by Bui (2020a).

Table 4. Estimation results

\begin{tabular}{|l|l|l|}
\hline Dependent variable: House price (PRICE) & Coef. & $\mathbf{P}>|\mathbf{z}|$ \\
\hline Variables & $17.093^{* * *}$ & 0.000 \\
\hline Constant & $0.001^{* *}$ & 0.023 \\
\hline SIZE & $0.065^{* * *}$ & 0.000 \\
\hline BEDROOMS & 0.003 & 0.640 \\
\hline BATHROOMS & $-0.020^{* * *}$ & 0.000 \\
\hline CENTER & $0.048^{* *}$ & 0.036 \\
\hline TYPE & 0.002 & 0.709 \\
\hline POOL & $0.187^{* * *}$ & 0.000 \\
\hline PARK & $0.050^{* * *}$ & 0.000 \\
\hline STRUCTURE & 205 & \\
\hline Number of obs & $85.59 \%$ \\
\hline R-squared & $\mathrm{F}(8,196)=276.08$ \\
\hline Significance level & Prob $>\mathrm{F}=0.000^{* * * *}$ \\
\hline
\end{tabular}

Note: ${ }^{* *}$ and ${ }^{* * *}$ indicate significance at the $5 \%$ and $1 \%$ level, respectively.

Source: own study.

As can be seen from Table 4, the estimation results are significant at the $1 \%$ level (Prob $>\mathrm{F}=0.000)$. Specifically, the independent variables can account for $85.59 \%$ variation in house price. It can be concluded that the model is appropriate and valid for the practical application. Alternatively, the hedonic pricing model is successfully applied in estimating house price in Vietnam. Furthermore, with a high explanation level of research model and highly-representative dataset, the results can be widely administered.

Particularly, CENTER exerts the negative impact $(\beta=-0.020)$ on PRICE at $1 \%$ level of significance whereas PRICE is positively influenced by SIZE ( $\beta=0.001$, at $5 \%$ level of significance), BEDROOMS ( $\beta=0.065$, at $1 \%$ level of significance), TYPE $(\beta=0.048$, at $5 \%$ level of significance), PARK $(\beta=0.187$, a $1 \%$ level of significance), STRUCTURE ( $\beta=0.050$, at $1 \%$ level of significance). Nevertheless, 
the study has not found the significant influence of BATHROOMS and POOL on PRICE. Hence, the estimated results of the model take the following equation:

PRICE $=17.093+0.001$ SIZE +0.065 BEDROOMS -0.020 CENTER + 0.048 TYPE +0.187 PARK +0.050 STRUCTURE $+\varepsilon$

Table 5. Results of hypothesis testing

\begin{tabular}{|l|l|l|}
\hline No & Hypothesis & Results \\
\hline $\mathrm{H}_{1}$ & SIZE $\Rightarrow$ PRICE & Accepted \\
\hline $\mathrm{H}_{2}$ & BEDROOMS $\Rightarrow$ PRICE & Accepted \\
\hline $\mathrm{H}_{3}$ & BATHROOMS $\Rightarrow$ PRICE & Rejected \\
\hline $\mathrm{H}_{4}$ & CENTER $\Rightarrow$ PRICE & Accepted \\
\hline $\mathrm{H}_{5}$ & TYPE $\Rightarrow$ PRICE & Accepted \\
\hline $\mathrm{H}_{6}$ & POOL $\Rightarrow$ PRICE & Rejected \\
\hline $\mathrm{H}_{7}$ & PARK $\Rightarrow$ PRICE & Accepted \\
\hline $\mathrm{H}_{8}$ & STRUCTURE $\Rightarrow$ PRICE & Accepted \\
\hline
\end{tabular}

Source: Own study.

- The impact of house size (SIZE) on house price (PRICE): The results show that SIZE positively affects PRICE. This indicates that houses in bigger size are usually priced more. This finding corroborates the reality and what has been reported by Kain and Quigley (1970), Selim (2009), Amenyah and Fletcher (2013), Shimizu (2014), Yayar and Demir (2014), Ndegwa (2018). Accordingly, big-size houses can meet demand of crowded families, bringing a wide and comfortable space. These houses can also specially be used for their business or offices.

- The impact of the number of bedrooms (BEDROOMS) on house price (PRICE): The results show that BEDROOMS positively affects PRICE. This is consistent with the findings of Kain and Quigley (1970), Cebula (2009), Selim (2009), Baek et al. (2019). Accordingly, houses with more bedrooms suit families with many members. These houses allow their guests to stay over. As a result, they are more expensive.

- The impact of house location (CENTER) on house price (PRICE): The study supports the negative influence of CENTER on PRICE. This shows that houses far from the center may sell for less than those with a close proximity to the center. This is because people living in the former find it difficult to commute to work or town center. Also, their public amenities are more limited than the latter. This is in line with the results in the studies of Selim (2009), Aluko (2011), Amenyah and Fletcher (2013), Yayar and Demir (2014), Ndegwa (2018).

- The impact of house type (TYPE) on house price (PRICE): The findings reveal that PRICE is positively affected by TYPE. In the metropolises with a high population, the presence of garden in a house can help improve people's living standard. Consequently, this kind of house is higher priced. This finding is consistent with what has been stated by Limsombunchai et al. (2004). 
- The impact of local amenities (PARK) on house price (PRICE): The study establishes the positive influence of PARK on PRICE. Houses which are located near parks, squares, schools or shopping malls are more preferred because of their convenience for entertainment, study or shopping. They are, thus, sold at a high value. This corroborates with the findings of Cebula (2009), Selim (2009), Amenyah and Fletcher (2013), Ndegwa (2018).

- The impact of house structure (STRUCTURE) on house price (PRICE): The study shows that PRICE is positively influenced by STRUCTURE. This result has also been found in the analysis of Cebula (2009). Houses with new and modern structure are obviously more preferred and higher priced.

\section{Conclusions}

By this study, the author greatly succeeded in giving first empirical evidence on applying the hedonic pricing model to estimate house value in Vietnam. In addition, the results can be practically applied widely. The results reveal that the proximity to the center negatively affects the house price. Meanwhile, houses with big size, modern new structure, more bedrooms, gardens and local amenities (like squares, parks, schools, shopping malls) are more valuable. Based on these results, housing market participants can make an accurate prediction on housing prices. Indeed, based on the results, the management in the housing market can have a comprehensive perspective on this market, especially the factors affecting house price. This is essential for them to come up with suitable solutions boosting an efficient and sustainable housing market. More than that, the results enable the management to successfully develop a highly-representative house price index in Vietnam. The results can be widely applied by appraisers at a low cost while the investors can introduce high-valued houses which meet customer's demands. To distributors, it facilitates the improvement of distribution channels, so their projects can be introduced quickly and effectively to customers. The results also allow buyers to determine the real value of a house easily. In addition, these findings are valuable reference for other countries, especially those with a nascent housing market like Vietnam.

Despite achieving its objective, the study still has its own limitation when not analyzing other determinants which may affect the house price such as macroeconomic factors, investor's prestige and housing distribution channel's performance. These may be interesting proposals for future studies.

\section{References:}

Abidoye, R.B., Chan, A.P.C. 2017. Critical review of hedonic pricing model application in property price appraisal: A case of Nigeria. International Journal of Sustainable Built Environment, 6(1), 250-259. https://doi.org/10.1016/j.ijsbe.2017.02.007 
Aluko, O. 2011. The effects of location and neighborhood features on housing values in Metropolitan Lagos. Ethiopian Journal of Environmental Studies and Management, 4(2), 69-88. http://dx.doi.org/10.4314/ejesm.v4i2.8

Amenyah, I.D., Fletcher, E.A. 2013. Factors determining residential rental prices. Asian Economic and Financial Review, 3(1), 39-50. Retrieved from http://www.aessweb.com/pdf-files/39-50.pdf

Antipov, E.A., Pokryshevskaya, E.B. 2012. Mass appraisal of residential apartments: an application of random forest for valuation and a CART-based approach for model diagnostics. Expert Systems with Applications, 39(2), 1772-1778. https://doi.org/10.1016/j.eswa.2011.08.077

Baek, U., Sim, Y., Lee, S.K. 2019. Analysis of Hierarchical Competition Structure and Pricing Strategy in the Hotel Industry. Journal of Asian Finance, Economics and Business, 6(4), 179-187. https://doi.org/10.13106/jafeb.2019.vol6.no4.179

Bui, T.N. 2019. The role of financial development in the Vietnam economy. WSEAS Transactions on Business and Economics, 16, 471-476. Retrieved from https://www.wseas.org/multimedia/journals/economics/2019/a985107-854.pdf

Bui, T.N. 2020a. A study of factors influencing the price of apartments: Evidence from Vietnam. Management Science Letters, 10(10), 2287-2292. http://doi.org/10.5267/j.msl.2020.3.007

Bui, T.N. 2020b. Impacts of interest rate on housing prices: Evidence from Ho Chi Minh city, Vietnam. International Transaction Journal of Engineering, Management, \& Applied Sciences \& Technologies, 11(5), 1-7. http://doi.org/10.14456/ITJEMAST.2020.81

Cebula, R.J. 2009. The Hedonic Pricing Model applied to the housing market of the city of Savannah and its Savannah historic landmark district. The Review of Regional Studies, 39(1), 9-22. Retrieved from https://econpapers.repec.org/article/rrepublsh/v 3a39 3ay 3a2009 3ai 3a1 3ap 3a 9-22.htm

Frew, J., Jud, G.D. 2003. Estimating the value of apartment buildings. The Journal of Real Estate Research, 25(1), 77-86. https://doi.org/10.1080/10835547.2003.12091101

Friesen, D., Patterson, M., Harmel, B. 2011. A Comparison of multiple regression and neural networks for forecasting real estate values. Regional Business Review, 30, 114-136. Retrieved from https://www.nwmissouri.edu/academics/pdf/rbr/2011.pdf

Jeon, J.H. 2018. The Impact of Asian Economic Policy Uncertainty : Evidence from Korean Housing Market. The Journal of Asian Finance, Economics and Business, 5(2), 43 51. https://doi.org/10.13106/jafeb.2018.vol5.no2.43

Kain, J.F., Quigley, J.M. 1970. Measuring the value of housing quality. Journal of the American Statistical Association, 65(330), 532-548. Retrieved from https://www.tandfonline.com/doi/abs/10.1080/01621459.1970.10481102

Kilpatrick, J. 2011. Expert systems and mass appraisal. Journal of Property Investment \& Finance, 29(4/5), 529-550. https://doi.org/10.1108/14635781111150385

Kontrimas, V., Verikas, A. 2011. The mass appraisal of the real estate by computational intelligence. Applied Soft Computing, 11(1), 443-448. https://doi.org/10.1016/j.asoc.2009.12.003

Laurice, J., Bhattacharya, R. 2005. Prediction performance of a Hedonic Pricing Model for housing. Appraisal Journal, 73, 198-209.

Limsombunchai, V., Gan, C., Lee, M. 2004. House price prediction: Hedonic price model vs. artificial neural network. American Journal of Applied Sciences, 1(3), 193-201. https://doi.org/10.3844/ajassp.2004.193.201 
Lin, C.C., Mohan, S.B. 2011. Effectiveness comparison of the residential property mass appraisal methodologies in the USA. International Journal of Housing Markets and Analysis, 4(3), 224-243. Retrieved from https://econpapers.repec.org/article/emeijhmap/v_3a4_3ay 3a2011_3ai_3a3_3ap_3 a224-243.htm

McCluskey, W., Davis, P., Haran, M., McCord, M., McIlhatton, D. 2012. The potential of artificial neural networks in mass appraisal: the case revisited. Journal of Financial Management of Property and Construction, 17(3), 274-292. https://doi.org/10.1108/13664381211274371

McCluskey, W.J., McCord, M., Davis, P.T., Haran, M., McIlhatton, D. 2013. Prediction accuracy in mass appraisal: a comparison of modern approaches. Journal of Property Research, 30(4), 239-265. https://doi.org/10.1080/09599916.2013.781204

Ndegwa, J.N. 2018. Determinants of apartment prices within housing estates of Nairobi metropolitan area. International Journal of Economics and Finance, 10(6), 104-111. https://doi.org/10.5539/ijef.v10n6p104

Nghiep, N., Al, C. 2001. Predicting housing value: A comparison of multiple regression analysis and artificial neural networks. Journal of Real Estate Research, 22(3), 313336. Retrieved from https://www.tandfonline.com/doi/abs/10.1080/10835547.2001.12091068

Nguyen, M.L.T., Bui, T.N. 2019. Stock market, real estate market, and economic growth: an ARDL approach. Investment Management and Financial Innovations, 16(4), 290302. http://dx.doi.org/10.21511/imfi.16(4).2019.25

Nguyen, M.L.T., Bui, T.N., Nguyen, T.Q. 2019. Relationships between real estate markets and economic growth in Vietnam. Journal of Asian Finance, Economics and Business, 6(1), 121-128. http://doi.org/10.13106/jafeb.2019.vol6.no1.121

Nguyen, H.C., Do, D.T. 2020. Factors Influencing the Perception of the Selling Price of Luxury Apartments. The Journal of Asian Finance, Economics and Business, 7(5), 185-194. https://doi.org/10.13106/jafeb.2020.vol7.no5.185

Nguyen, M.L.T., Pham, T.T.X, Bui, T.N. 2020. Causal relationship between banking system development and real estate market. Management Science Letters, 10(1), 41-52. https://doi.org/10.5267/j.msl.2019.8.017

Peterson, S., Flanagan, A.B. 2009. Neural network hedonic pricing models in mass real estate appraisal. Journal of Real Estate Research, 31(2), 147-164. Retrieved from https://www.tandfonline.com/doi/abs/10.1080/10835547.2009.12091245

Renigier-Biłozor, M., Janowski, A., d'Amato, M. 2019. Automated valuation model based on fuzzy and rough set theory for real estate market with insufficient source data. Land Use Policy, 87, 1-11. https://doi.org/10.1016/j.landusepol.2019.104021

Schulz, R., Werwatz, A. 2004. A state space model for Berlin House prices: Estimation and economic interpretation. Journal of Real Estate Finance and Economics, 28(1), 3757. https://doi.org/10.1023/A:1026373523075

Shimizu, C. 2014. Estimation of Hedonic single-family house price function considering neighborhood effect variables. Sustainability, 6, 2946-2960. https://doi.org/10.3390/su6052946

Selim, H. 2009. Determinants of house prices in Turkey: Hedonic regression versus artificial neural network. Expert Systems with Applications, 36, 2843-2852. https://doi.org/10.1016/j.eswa.2008.01.044

Sirmans, G.S., Macpherson, D.A., Zietz, E.N. 2005. The composition of Hedonic Pricing Models. Journal of Real Estate Literature, 13, 3-43. Retrieved from https://www.jstor.org/stable/44103506?seq=1 
White, H. 1980. A heteroscedasticity-consistent covariance matrix es timator and a direct test for heteroscedasticity. Econometrica, 48(4), 817-838. Retrieved from https://www.jstor.org/stable/1912934?seq=1

Yayar, R., Demir, D. 2014. Hedonic estimation of housing market prices in Turkey. Makalenin kabul tarihi: Temmuz, 43, 67-82. Retrieved from https://www.academia.edu/10649981/HEDONIC ESTIMATION_OF_HOUSING MARKET_PRICES IN TURKEY

Zurada, J., Levitan, A.S., Guan, J. 2011. A comparison of regression and artificial intelligence methods in a mass appraisal context. Journal of Real Estate Research, 33(3), 349-387. Retrieved from https://www.tandfonline.com/doi/abs/10.1080/10835547.2011.12091311 